\title{
EDUCATION OF THE PHYSICIST
}

\begin{abstract}
$\Delta \mathrm{T}$ the recent Bristol meeting of the British A Association a recurrent theme in addresses to several sections was the specialist, and what should be done about him. Mr. J. F. Wolfenden, president of Section L (Education), spoke of the 'educated man' in 1955 as the man who could walk in the two great fields of thought, that of human aspirations and endeavour to which he would come through the humanities, and that of abstract thought and control over Nature to which man comes through science. Following him and speaking on the educated man in 1984, Dr. J. Bronowski threatened the world with Orwellian consequences if the schools and universities did not follow Mr. Wolfenden's advice; and Mr. Ritchie Calder, speaking as president of Section X (the Assembly of Corresponding Societies), accused scientists of knowing little in science itself outside each man's own speciality, and of being unable to achieve or communicate any broad picture of the state or meaning of science.
\end{abstract}

Mainly on this theme, a session on September 5 was organized jointly by Section A (Physics and Mathematics) and Section L (Education), devoted to the "Education of the Physicist", under the chairmanship of Mr. Wolfenden. The aims of the organizers were these: schools in Britain are frequently accused of over-specialization; Is this accusation just? Would anyone defend the present state of affairs? If the education of scientists is too specialized, where must we look for the remedy-to the schools or the universities? And would any remedies that might be suggested increase or decrease the number of boys who choose science? Finally, how, if at all, can we produce Mr. Wolfenden's educated man, the man who is equally at home in the humanities and in science?

The first speaker was Sir Philip Morris, vicechancellor of the University of Bristol, who said that the central problem in education is the impact of the great increase in knowledge, particularly scientific knowledge, and its vastly increased importance. He feels that our primary education is notably successful, but that the secondary stago is the heart of our educational problem to-day. The idea of secondary education for all has caught men's imagination, as something we want and ought to have, but ideas as to what this edueation ought to be are shadowy, lacking coherent form and definite substance.

Interest in physics and the desire to make a career in the subject, or indeed in any other branch of science, . normally show themselves during the secondary stage of a school education. The choice that a boy will make is partly a matter of natural aptitude, but partly a matter of the opportunities presented to him at school and the influences brought to bear on him. Sir Philip strongly emphasized how great is the influence of the secondary school, whether deliberate or not, in shaping the lives of the children who go there and in guiding them towards careers. $\mathrm{He}$ therefore thinks that a balance between the linguistic, the mathematical and the scientific is of the greatest importance during the first five years of the secondary school course, so that a child will have every opportunity to follow where his true abilities and ambition lie.
Sir Philip thinks that we have deviated more from a properly balanced education than we ought in these first five years. The problems that physicists in particular ought to ask themselves are: How vital is mathematical knowledge to the school child's appreciation of science? And should the sciences at this stage be taught as separate subjects? It is of the utmost importance that every secondary school pupil should learn about the scientist's outlook on the physical universe; Sir Philip placed this aim above, though not necessarily in opposition to, a preliminary grounding in particular scientific subjects.

In the last two or three years before the university, particular subjects chosen from those found in them must be followed seriously and deeply, but even so the course must have some balance. Much has been written on the educative value of a purely scientific education, and certainly really imaginative teachers can use science to provide for their pupils a full range of spiritual, emotional, social and political experience. But Sir Philip doubts the wisdom of making the attempt, and feels it better that science teachers should do their best to persuade their pupils of the importance of subjects outside their speciality and should leave it to others to teach these subjects.

Prof. N. F. Mott, Cavendish professor of physics in the University of Cambridge, spoke of his experience in interviewing candidates for admission to the University of Bristol when he was head of the Physics Department there, and the number of students who had said that, apart from their specialist studies, their curriculum included as little as one period of scripture, one of English, one of civics and one of gymnasties. Whether or not this was a fair description of the curriculum in many schools, it seems to him to indicate that in the boys' minds the subjects outside their specialization are treated with little respect. He believes that at least one arts subject, such as a modern language, should be continued seriously until the end of their time in the sixth form; and he believes that the sixth form rather than the university is the place where the basis of a general education should be laid. To widen the curriculum there would have two advantages. It would narrow the widely deplored gap between scientists and arts men, and it would defer the moment in a child's life when he has to choose between science and other subjects.

Prof. Mott then went on to discuss ways in which the universities could help the schools to widen the sixth form education with these ends in view. One way is to provide a means of entry into science faculties for those who have not specialized or have specialized late. Such opportunities already exist in the form of the Intermediate course, but Prof. Mott sees the passibility of an ambitious university, in co-operation with the Ministry of Education, founding a strong Intermediate course as the basis of a fouryear course of study. He said he would like to seo an increased emphasis on the 'General Paper' in scholarship examinations, and a renewed assurance given to the schools that this paper would be given a big role in awarding scholarships at Oxford and Cambridge. Another possibility is that a group of colleges would give an assurance that they would 
offer each year a certain number of mixed scholar. ships in which a candidate would take both arts and science subjects. Such scholarships do exist at Cambridge, but few candidates of high quality enter for them; nor, he thought, would the schools attempt this kind of education, unless they knew that scholarships would be reserved for candidates of this kind.

Another possibility might be that a group of colleges could set a qualifying examination, say one year before the entrance scholarship examination, in an arts subject. It would not be compulsory, but candidates who passed it would have a certain percentage of scholarships reserved for them. They would take the same papers in science as the specialists, but would not be in competition with them.

Prof. Mott felt that the right solution could best be obtained by a given university or college working in co-operation with a group of schools, rather than by experiments on a national scale.

Prof. F. A. Vick, head of the Department of Physics of the University College of North Staffordshire, agreed with Sir Philip Morris that courses in physics can be designed which contain everything that a complete education should have, and he went further than Sir Philip in believing that they should be so designed. He believes that they should teach a good fundamental knowledge of the subject and at the same time develop insight and imagination-as important in the physical sciences as in any other creative activity of the human mind-intellectual courage and honesty, understanding of scientific proof, ability to assess a situation, logical thought, clarity and precision of expression, experimental skill, ability to handle abstract ideas, judgment, recognition of the limitations of science, and humility in face of the wonders and mysteries of Nature.

An interesting suggestion brought out in Prof. Vick's paper was that he would advocate founding in some university a school which would stand alongside the Oxford 'Greats' and 'Modern Greats', and which would contain physics as a major component. Philosophy, physics and economics might be combined in such a course-P. P*. E. he called it. As a firm believer in the educational value of physics, he thinks that such a course would admirably equip the politicians, Civil servants and industrialists of the modern world. Prof. Vick's experience in teaching physics to arts students in courses lasting one or two sessions at the University College of North Staffordshire has convinced him that some of them become very interested in the subject, and are prepared to work hard in it, even if they would not wish to become professional physicists, and that they would be capable of doing well in a P. P*. E. combination. Even with the comparatively short courses at subsidiary level, the potential barrier which so often exists between an arts man and any science is penetrated or broken down. The whole outlook of the student is broadened.

Dr. A. W. Barton, headmaster of the City of London School, maintained in agreement with the other speakers that the school is just as important as the university; in particular, it has to choose the future scientists. He told how this is done at the City of London School. In the last resort, the choice is made by the boy and his parents; but Dr. Barton was emphatic that, in view of the needs of the community, the school would be right to lay strongly before a boy the advantages of a scientific career.

Dr. Barton does not think that the average physicist specializes too much at school. In the first four years he will spend two-thirds of his time on the humanities, and in the last three years one-third or one-quarter; and he does not think that Prof. Mott's "one period each of scripture, English, gym. and civics" is typical. Moreover, he believes that the sixth-form education is more liberal than it was forty years ago. Neither does he think that the competitive nature of the Oxford and Cambridge entrance scholarship leads to excessive specialization. The questions now set test no more ground than they did thirty-nine years ago. $\mathrm{He}$ thinks that the potential scholar is quite capable of answering these papers without being unduly pressed and without spending more than a reasonable time on science. It may well be that some pupils are over-specializing in the attempt to reach the standard of these papers; but that is not the fault of the papers, but of the schools in trying to prepare unsuitable pupils for them, and will soon disappear now as local authorities give reasonable assistance to potential physicists to go to the university even if they are well below the standard of an open scholarship.

\section{BRITISH SEISMOLOGY DURING 1954-55}

$T$ HE sixtieth annual report of the Committee for Seismological Investigations appointed by the British Association, covering the work done by British seismologists during the year 1954-55, was presented to Section A (Physics and Mathematics) of the Association at its recent Bristol meeting. As part of the work carried out in the Department of Geodesy and Geophysics at Cambridge, Dr. M. N. Hill has continued his seismic refraction-shooting experiments in the English Channel and the Western Approaches. From the results obtained at a line of stations extending down the middle of the English Channel from the Greenwich meridian to the longitude of Weymouth, it was found that the depth to the palæozoic floor varied between 2,400 and $3,500 \mathrm{ft}$. These figures are smaller than had been expected by Dr. Hill. Dr. R. Stoneley has investigated the problem of the propagation of surface waves in a medium with cubic symmetry, the free surface of which is a principal plane. The propagation of waves of Rayleigh type is not possible for all values of the density and the three elastic constants; but when it is possible, the wave velocity depends on the direction of propagation. For the symmetrical cases of transmission along a principal axis, or along a bisector of two perpendicular principal axes in the free surface, Rayleigh wave-motion can occur, in which the particles describe ellipses in a retrograde direction. In these cases only can transverse motion (as in Love waves) exist by itself. In the general case the plane of the particles is inclined to the plane of propagation; in fact, the separation in an isotropic solid into Rayleigh waves and transverse motion occurs as a mathematically degenerate case of this general type of motion.

At the University of Durham Observatory, the building of an underground chamber for the seismographs has begun, and it is estimated that, when completed, the diurnal temperature variation in it will not exceed 1 deg. F. The director, Mr. E. F. Baxter, hopes shortly to be in possession of a WilsonLamison vertical seismometer to complete a set of 